\title{
Electrochemical Corrosion Test Results for Tank 241-SY-102 Supernate Grab Samples
}

\author{
J, B. Duncan \\ CH2M HILL Hanford Group, Inc. \\ Richland, WA 99352 \\ U.S. Department of Energy Contract DE-AC27-99RL14047 \\ EDT/ECN: DRF UC: \\ Cost Center: 7\$110 Charge Code: \\ B\&R Code: $\quad$ Total Pages: 29
}

Key Words: electrochemical, corrosion, test, results, SY-102, SY-101, S-112, supernate, grab, samples, justification for continued operation, open circuit potential, tank, RPP-18195, RPP-PLAN-23585, electrode, counter electrode, thermocouple, scans, sample, ASTM G5-94, ASTM G61-86, AC 5.16

Abstract: This report describes the electrochemical corrosion scans and conditions for testing of SY-102 supcrnatant samples taken December 2004. The testing was performed because the tank was under a Justification for Continued Operation allowing the supernatant composition to be outside the chemistry limits of Administrative Control 5.16, "Corrosion Mitigation Program." $\Lambda$ new electrochemical working electrode of A516 Grade 60 carbon steel was used for each scan; all scans were measured against a saturated calomel electrode, with carbon counter electrodes, and all scans were carried out at $50^{\circ} \mathrm{C}$. The samples were scanned twice, once as received and onee sparged with argon to deoxygenate the sample. For those scans conducted after argon purging, the corrosion rates ranged from 0.012 to $0.019 \mathrm{mpy}$. A test for stress corrosion cracking was carried out on one sample (2SY-04-07) with negative results.

TRADEMARK DISCLAIMER. Reference herein to any specific commercial product, process, or service by trade name, trademark, manufacturer, or otherwise, does not necessarly constitute or imply its endorsement, recommendation, or favoring by the United States Govemment or any agency thereof or its contraciors or subcontractors.

Printed in the United States of America. To obtain copies of this document, contact Document Control Services. P.O. Box 950, Mailstop H6-08, Richland WA 99352, Phone (509) 372-2420; Fax (509) 376-4989.

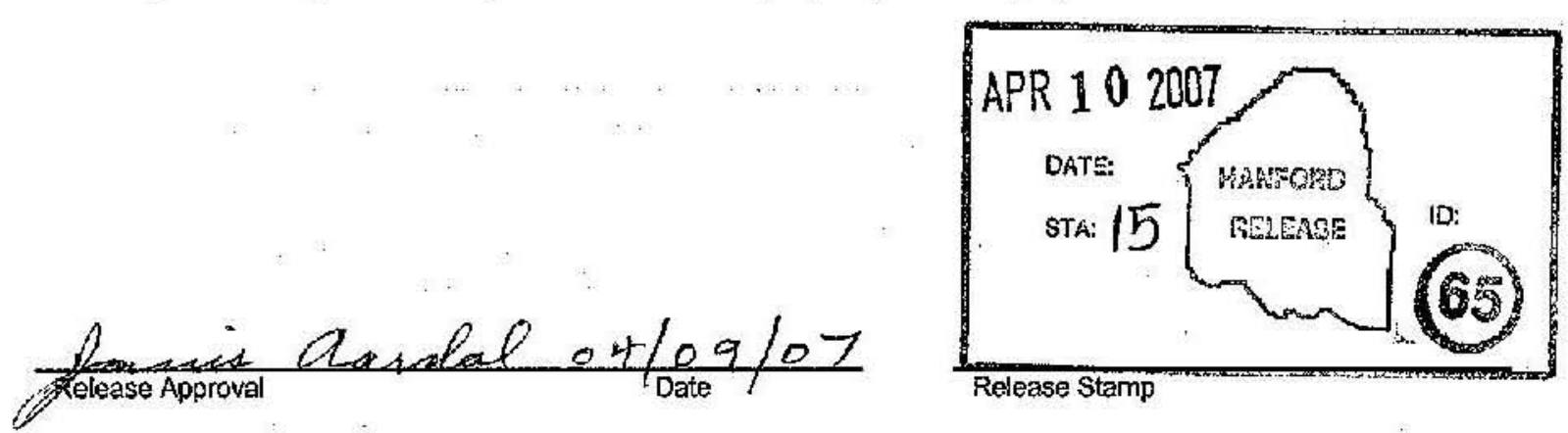

Approved For Public Release 
RPP-RPT-27766

Revision 0

\title{
Electrochemical Corrosion Test Results for Tank 241-SY-102 Supernate Grab Samples
}

\author{
J. B. Duncan \\ CH2M HILL Hanford Group, Inc.
}

Date Published

April 2007

Hanford Group, inc.

Prepared for the U.S. Department of Energy

Office of River Protection

Contract No. DE-AC27-99RL14047 
RPP-RPT-27766, Rev. 0

\section{Table of Contents}

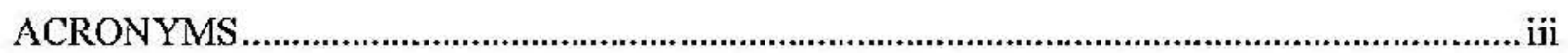

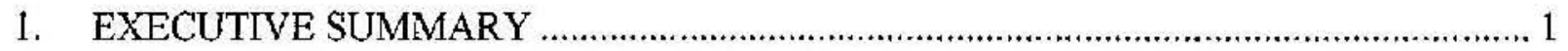

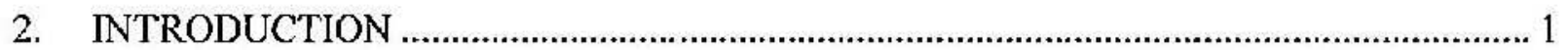

3. DESCRIPTION OF TANK 241-SY-102 SUPERNATE

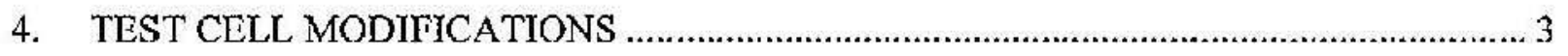

5. ELECTROCHEMICAL TESTS of MODIFIED TEST CELL …...................................... 4

5.1 125-MILLILITER ELECTROCHEMICAL CELL ..................................................... 5

5.2 250-MILLILITER ELECTROCHEMICAL CELL ................................................... 6

6. TANK 241-SY^102 SUPERNATANT TEST RESULTS …….......................................... 7

6.1 DESCRIPTION OF ELECTROCHEMICAL SCANS............................................ 7

6.2 INSTRUMENT AND LEAD VERIFICATION TESTS........................................... 8

6.3 RESULTS AND DISCUSSION OF ELECTROCHEMICAL SCANS ........................ 9

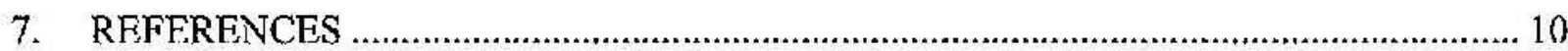

APP'ENDIX A CYCLIC POLARIZATIION SCANS TANK 241-SY-102

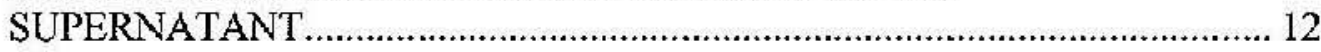

Figures

Figure 1. Plan View of Electrochemical Cell Lid with Two Counter Electrodes......................... 5

Figure 2. Response of the 125-Milliliter Electrochemical Cell using the ASTM G5 94

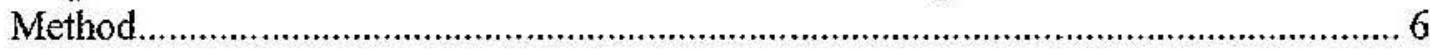

Figure 3. Response of the 250-Milliliter Electrochemical Cell using ASTM G5 94 Method....... 6

Figure 4. Plan View of Electrochemical Ccll Lid with Two Counter Elcetrodes...................... 7

Figure 5. Electrochemical Response to ASTM G5-94 Method................................................. 8

Figurc A-1. Sample 2SY-04-05, without Argon Sparge, Potential Measured against a Saturated Calomel Electrode, Scan Temperature 50 ${ }^{\circ} \mathrm{C}$............................................ 13

Figure A-2. Sample 2SY-04-06, without Argon Sparge, Potential Measured against a Saturated Calomel Electrode, Scan Temperature $50^{\circ} \mathrm{C}$.............................................. 14

Figure A-3. Sample 2SY-04-06 DUP, without Argon Sparge, Potential Measured against a Saturated Calomel Electrode, Scan Temperature $50^{\circ} \mathrm{C}$.............................................. 15

Figure A-4. Sample 2SY-04-07, without Argon Sparge, Potential Measured against a Saturated Calomel Electrode, Scan Temperature $50^{\circ} \mathrm{C}$.............................................. 16

Figure A-5. Sample 2SY-04-08, without Argon Sparge, Potential Measured against a Saturated Calomel Electrode, Scan Temperature $50^{\circ} \mathrm{C}$ 


\section{RPP-RPT-27766, Rev. 0}

Figure A-6. Sample 2SY-04-05, with Argon Sparge, Potential Measured against a Saturated Calomel Electrode, Scan Temperature $50^{\circ} \mathrm{C}$..................................................... 18

Figure A-7. Sample 2SY-04-06, with Argon Sparge, Potential Measured against a Saturated Calomel Electrode, Scan Temperature $50^{\circ} \mathrm{C}$.......................................................... 19

Figure A-8. Sample 2SY-04-06 DUP, with Argon Sparge, Potential Measured against a Saturated Calomel Electrode, Scan Temperature $50^{\circ} \mathrm{C}$

Figure A-9. Sample 2SY-04-07, with Argon Sparge, Potential Measured against a Saturated

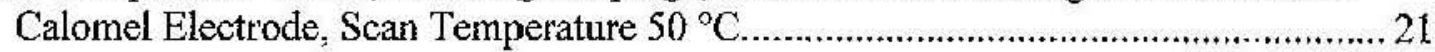

Figure A-10. Sample 2SY-04-08, with Argon Sparge, Potential Measured against a Saturated Calomel Electrode, Scan Temperature $50^{\circ} \mathrm{C}$

Figure A-1 1. Fast and Slow Scan Overlays for the Parkin Method for Stress Corrosion Cracking against a Saturated Calomel Electrode, Scan Temperature $50^{\circ} \mathrm{C}$.

Tables

Table 1. Double-Shell Tank Limits for Temperatures below $167^{\circ} \mathrm{F}$...................................... 2

Table 2. Sample Description.............................................................................................. 3

Table 3. Analytical Chemistry Results and Conditions Established by Table 5.16-1.................. 4

Table 4. Results of Electrochemical Cyctic Polarization Scans for Tank 241-SY-102

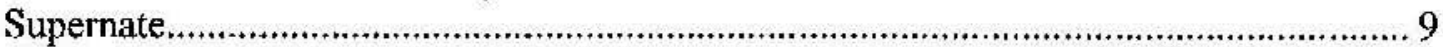


RPP-RPT-27766, Rev. 0

\section{ACRONYMS}

CE

$\mathrm{JCO}$

mpy

OCP

ORP

S-112

SY-101

SY-102

TOC

WE
Counter electrode

Justification for Continued Operation

mils per year

Open circuit potential

U.S. Department of Energy, Office of River Protection

tank 241-S-112

tank 241-SY-101

tank 241-SY-102

total organic carbon

working electrode 
RPP-RPT-27766, Rev. 0

\section{EXECUTIVE SUMMARY}

This report describes the electrochemical corrosion scans and conditions for testing of tank 241-SY-102 (SY-102) supernatant samples taken December 2004 under RPP-18195, Tank 24I-SY-102 Grab Sampling and Analysis Plan: Transfer and Retrieval Support. The testing was performed because the tank was under a Justification for Continued Operation (JCO) allowing the supernatant composition to be outside the chemistry limits of HNF-SD-WM-TSR-006, Tank Farms Technical Safety Requirements, Administrative Control (AC) 5.16, "Corrosion Mitigation Program." RPP-PLAN-23585, Test Plan and Procedure for Electrochemical Corrosion Studies of Tank 241-SY-102 Supernatant, provided the detailed description of the testing to be performed, including development of a small volume test cell for use with supernate and cyclic potentiodynamic testing of the five SY-102 samples. A new electrochemical working electrode of A516 Grade 60 carbon steel was used for each scan; all scans were measured against a saturated calomel electrode, with carbon counter electrodes, and all scans were carricd out at $50^{\circ} \mathrm{C}$. The samples were scanned twice, once as received and again purged with argon gas for 1 hour. Each clectrode was prepared just before use in the electrochemical cell located in the $11 \mathrm{~A} 3$ hot cell in the 222-S Laboratory. Corrosion rates were measured from 0.028 to 0.039 mils per year (mpy) for the as-received scans. For those scans conducted after argon purging, the corrosion rates ranged from 0.012 to $0.019 \mathrm{mpy}$. A test for stress corrosion cracking was carried out on one sample (2SY-04-07) with negative results.

\section{INTRODUCTION}

The double-shell tank SY-102 has been receiving single-shell tank waste from tank 241-S-112 (S-112) waste retrieval operations. Based on flow-sheet modeling (RPP-18694, Tank 241-S-112 Retrieval Process Flowsheet Calculation) performed for S-112 retrievals, the waste transferred into SY-102 will eventually force the tank chemistry below the HNF-SD-WM-TSR-006, Tank Farms Technical Safety Requirements, AC 5.16 chemistry control limits. As a result, the U.S. Department of Energy Office of River Protection (ORP) was approached and a JCO was requested allowing the waste in SY-102 to be outside of the AC 5.16 chemistry control limits. The JCO required implementation of three additional limiting conditions and was initially approved for a 1-year time period [letter 03-TED-117, "Contract No. DE-AC27-99RL14047Approval of Justification for Continued Operation (JCO) for Doublc-Shell Tank (DST) 241-SY-102" (letter 03-TED-117].

Waste rctricval in S-112 began September 28, 2003, with the first 220,000 gal translerred to double-shell tank 241-SY-101 (S-101). The receiver tank then switched to SY-102; since then transfers have intermittently occurred from S-112. Retrieval operations for S-112 have been quiescent for short periods since the start of operations in November 2003. Tank 241-SY-102 was initially sampled on December 4,2003, following receipt of approximately 350,000 gal of S-I12 waste. The sampling event indicated the waste in tank SY-102 remained within chemistry limits. Intermittent transfers from S-112 led to another sampling event on February 4, 2004. This sampling event indicated the hydroxide concentration of the surface supernatant 
layer was below the chemistry control limits. Additionally, the sum of the hydroxide and nitrite concentrations of the surface and middle supernatant layers were below the chemistry control limit of $1.2 \mathrm{M}$. The lower superuatant sample was within the required AC 5.16 chemistry control limits.

$\Lambda$ s mentioned above, the December 4,2003, sampling data indicated that SY-102 was within chemistry limits. The exact date that SY-102 fell below the chemistry control limits has not been established. December 17,2003 , the date of the first transfer from $\mathrm{S}-112$ following the December 2003 sample event, was selected as the out-of-specification date for the JCO 12-month period. Therefore, the tank was originally required to be returned to within AC 5.16 limits by December 17, 2004.

Schedule concems and process optimization planning led to a request for a JCO extension for the SY-102 chemistry in November (letter CH2M-0304014 R2, "Contract Number DE-AC2799RL14047 - Extension of Justification for Continued Opcration for Double-Shell Tank 241-SY-102). The tank waste chemistry was now allowed, as a result of an approved safety evaluation report from the ORP signed on December 2,2004, to be outside the AC 5.16 limits (Table 1), but within a new set of limits until June 17, 2005 [letter 03-IED-113, "Contract No. DE-AC27-99RL14047 - Approval of Justification for Continued Operation (J) for Double-Shell Tank (DST) 241-SY-102"].

Table 1. Double-Shell Tank Limits for Temperatures below $167^{\circ} \mathrm{F}$.

\begin{tabular}{|c|c|c|}
\hline For $\left[\mathrm{NO}_{3}\right]$ Range & Variable & $\mathbf{T}<167^{\circ} \mathbf{F}$ \\
\hline \multirow{2}{*}[\mathrm{NO}_{3}^{-}]{$\leq 1.0 \mathrm{M}$} & {$\left[\mathrm{OH}^{-}\right]$} & $0.010 \mathrm{M} \leq[\mathrm{OH}] \leq 8.0 \mathrm{M}$ \\
\cline { 2 - 3 } & {$\left[\mathrm{NO}_{2}^{-}\right]$} & $0.011 \mathrm{M} \leq\left[\mathrm{NO}_{2}\right] \leq 5.5 \mathrm{M}$ \\
\cline { 2 - 3 } & {$\left[\mathrm{NO}_{3}^{-}\right] /\left(\left[\mathrm{OH}^{-}\right]+\left[\mathrm{NO}_{2}^{-}\right]\right)$} & $\leq 2.5$ \\
\hline \multirow{2}{*}{$1.0 \mathrm{M} \leq\left[\mathrm{NO}_{3}^{-}\right] \leq 3.0 \mathrm{M}$} & {$\left[\mathrm{OH}^{-}\right]$} & $0.1\left(\left[\mathrm{NO}_{3}^{-}\right] \leq\left[\mathrm{OH}^{-}\right]<10 \mathrm{M}\right.$ \\
\cline { 2 - 3 } & {$\left[\mathrm{OH}^{-}\right]+\left[\mathrm{NO}_{2}^{-}\right]$} & $\geq 0.4\left(\left[\mathrm{NO}_{3}^{-}\right]\right)$ \\
\hline \multirow{2}{*}[\mathrm{NO}_{3}^{-}]{$>3.0 \mathrm{M}$} & {$\left[\mathrm{OH}^{-}\right]$} & $0.3 \mathrm{M}<\left[\mathrm{OH}^{-}\right]<10 \mathrm{M}$ \\
\cline { 2 - 3 } & {$\left[\mathrm{OH}^{-}\right]+\left[\mathrm{NO}_{2}^{-}\right]$} & $\geq 1.2 \mathrm{M}$ \\
\cline { 2 - 3 } & {$\left[\mathrm{NO}_{3}^{-}\right]$} & $\leq 5.5 \mathrm{M}$ \\
\hline
\end{tabular}

A multidepth grab sample event for SY-102 was completed on December 28, 2004, prior to the imminent waste transfer to SY-101. This sampling event will provide data on the current waste composition and support engineering analysis of a potential chemical adjustment needed to ensure SY-101 will remain within the AC 5.16 limits when the transfer oceurs.

The retrieval of saltcake waste using water results in salts and hydroxide concentrations being diluted, forcing the waste chemistry outside the specification. Chemistry control as a result of single-shell tank, or saltcake, retrieval projects will be a recurring problem over time as more 
tanks are retrieved. Effects of the diluted waste on the corrosion properties of the tank are not well understood. Electrochemical analysis of these supernatants with varying chemical compositions will enhance understanding of the corrosion behavior of the tank and wastes permitting better management of retrieval and waste storage operations.

\section{DESCRIPTION OF TANK 241-SY-102 SUPERNATE}

Five grab samples (2SY-04-05, 2SY-04-06, 2SY-04-06 DUP, 2SY-04-07, and 2SY-04-08) werc taken from Riser 3 of SY-102. The sample descriptions are presented in Table 2.

Table 2. Sample Description.

\begin{tabular}{|l|l|l|}
\hline Sample Number & $\begin{array}{c}\text { Sot } \\
\text { Settled } \\
\text { Solids }\end{array}$ & \multicolumn{1}{c|}{ Sample Description } \\
\hline 2SY-04-05 & $<2$ & $\begin{array}{l}\text { Clear yellow liquid no organic layer, floating trace black solids; } \\
\text { sample taken at 271.2 in. from the bottom of the tank to the mouth of } \\
\text { the sample bottle. }\end{array}$ \\
\hline 2SY-04-06 & $<2$ & $\begin{array}{l}\text { Clear yellow liquid no organic layer, floating trace black solids; } \\
\text { sample taken at 256.2 in. from the bottom of the tank to the mouth of } \\
\text { the sample bottle. }\end{array}$ \\
\hline 2SY-04-06 DUP & $<2$ & $\begin{array}{l}\text { Clear yellow liquid no organic layer, no solids; sample taken at } \\
256.2 \text { in. from the bottom of the tank to the mouth of the sample } \\
\text { bottle. }\end{array}$ \\
\hline 2SY-04-07 & $<2$ & $\begin{array}{l}\text { Clear yellow liquid no organic layer, no solids; sample taken at } \\
117.2 \text { in. from the bottom of the tank to the mouth of the sample } \\
\text { bottle. }\end{array}$ \\
\hline 2SY-04-08 & 57 & $\begin{array}{l}\text { Clear yellow liquid no organic layer, floating trace black solids; } \\
\text { brown solids; sample taken at 55.2 in. from the bottom of the tank to } \\
\text { the mouth of the sample bottle. }\end{array}$ \\
\hline
\end{tabular}

${ }^{2}$ Sample description was taken from 11-A Breakdown Notes and client Chain of Custody description.

Table 3 shows the analytical results for hydroxide, nitrate, nitrite, and total organic carbon. As may be determined from Table 3, the chemistry was in specification with the exception of the summation of the molar concentrations of hydroxide and nitrite, except for 2SY-04-08 which was within the chemistry boundaries. Table 3 also shows that the total organic carbon ranges from $1.2 \mathrm{~g} / \mathrm{L}$ to $2 \mathrm{~g} / \mathrm{L}$.

\section{TEST CELL MODIFICATIONS}

The anticipated sample volume for each sample of SY-102 was to be considerably less than the usual volume associated with tank sludge samples. Therefore, an electrochemical cell to analyze volumes of approximately 150 to $250 \mathrm{~mL}$ was devcloped. 
Tabfe 3. Analytical Chemistry Results ${ }^{2}$ and Conditions Established by Table 5.16-1.

\begin{tabular}{|c|c|c|c|c|c|c|}
\hline $\begin{array}{c}\text { Sample } \\
\text { (distance from } \\
\text { bottom, inches) } \\
\end{array}$ & OH $(M)$ & $\mathrm{NO}_{2}^{-}, M$ & $\begin{array}{l}\mathrm{NO}_{3}{ }^{-} \\
(M)\end{array}$ & $\begin{array}{c}\text { TOC } \\
(\mu \mathrm{gg} / \mathrm{mL}) \\
\end{array}$ & $\mathbf{p H}$ & $\begin{array}{c}\mathrm{OH}+\mathrm{NO}_{2} \\
(M)\end{array}$ \\
\hline $\begin{array}{l}2 S Y-04-05 \\
(271.2)\end{array}$ & 0.57 & 0.49 & 3.74 & $1.30 \mathrm{E} 3$ & $>13.5$ & 1.06 \\
\hline $\begin{array}{l}2 \mathrm{SY}-04-06 \\
(256.2)\end{array}$ & 0.58 & 0.50 & $\begin{array}{r}3.79 \\
\quad \\
\end{array}$ & $1.27 \mathrm{E} 3$ & $>13.5$ & 1.08 \\
\hline $\begin{array}{l}2 \mathrm{SY}-04-06 \mathrm{DUP} \\
(256.2)\end{array}$ & 0.57 & 0.50 & 3.79 & $1,20 \mathrm{E} 3$ & $>13.5$ & 1.07 \\
\hline $\begin{array}{l}\text { 2SY-04-07 } \\
(117.2)\end{array}$ & 0.55 & 0.49 & 3.71 & $1.29 \mathrm{E} 3$ & $>13.5$ & 1.04 \\
\hline $\begin{array}{l}2 S Y-04-08 \\
(55.2)\end{array}$ & 0.80 & 0.78 & 3.18 & $2.00 \mathrm{E} 3$ & $>13.5$ & 1.58 \\
\hline $\begin{array}{l}\text { Limits from Table } 1 \\
\text { for DST }>3.0 \mathrm{M} \\
{\left[\mathrm{NO}_{3}^{-}\right]}\end{array}$ & $\begin{array}{l}0.3 \mathrm{M}< \\
{[\mathrm{OH}]} \\
<10 \mathrm{M}\end{array}$ & $\mathrm{NA}$ & $>3 \mathrm{M}$ & NA & $>13.5$ & $\geq 1.2 \mathrm{M}$ \\
\hline
\end{tabular}

\footnotetext{
a Intemal letter 7S120-RWS-05-002, "Analytical Results for 24l-SY-102 Grab Sampling and Analysis Plan: Transfer and Retrieval Support."

TOC $=$ total organic carbon
}

\section{ELECTROCHEMICAL TESTS OF MODIFIED TEST CELL}

Two squat I-CHEM ${ }^{\mathrm{TM} 1}$ jars, $200-\mathrm{mL}$ and $300-\mathrm{mL}$ capacity, were used as the electrochcmical cell. The lids were constructed of Rexolite ${ }^{2}$ with ports for working electrode, counter electrodes, teference electrode, argon sparge, and vent.

To determine the efficacy of the test cell geometry, the ASTM G5-94, Standard Reference Test Method for Making Potentiostatic and Potentiodynamic Anodic Polarization Measurements, method was used to access the electrochemical cell response compared against the ASTM G5-94 data ranges.

Figure 1 is a schematic of the cell lid geometry for both the 125 and $250-\mathrm{mL}$ electrochemical cell.

\footnotetext{
${ }^{1}$ I-CIIEM is a registered trademark of I-CHEM Acquisition Co. Corporation, New Castle, Delaware.

${ }^{2}$ Rexolite is a registered trademark of C-LEC Plastics Inc., Corporation, Philadelphia, Pennsylvania.
} 


\section{Figure 1. Plan View of Electrochemical Cell Lid with} Two Counter Electrodes.

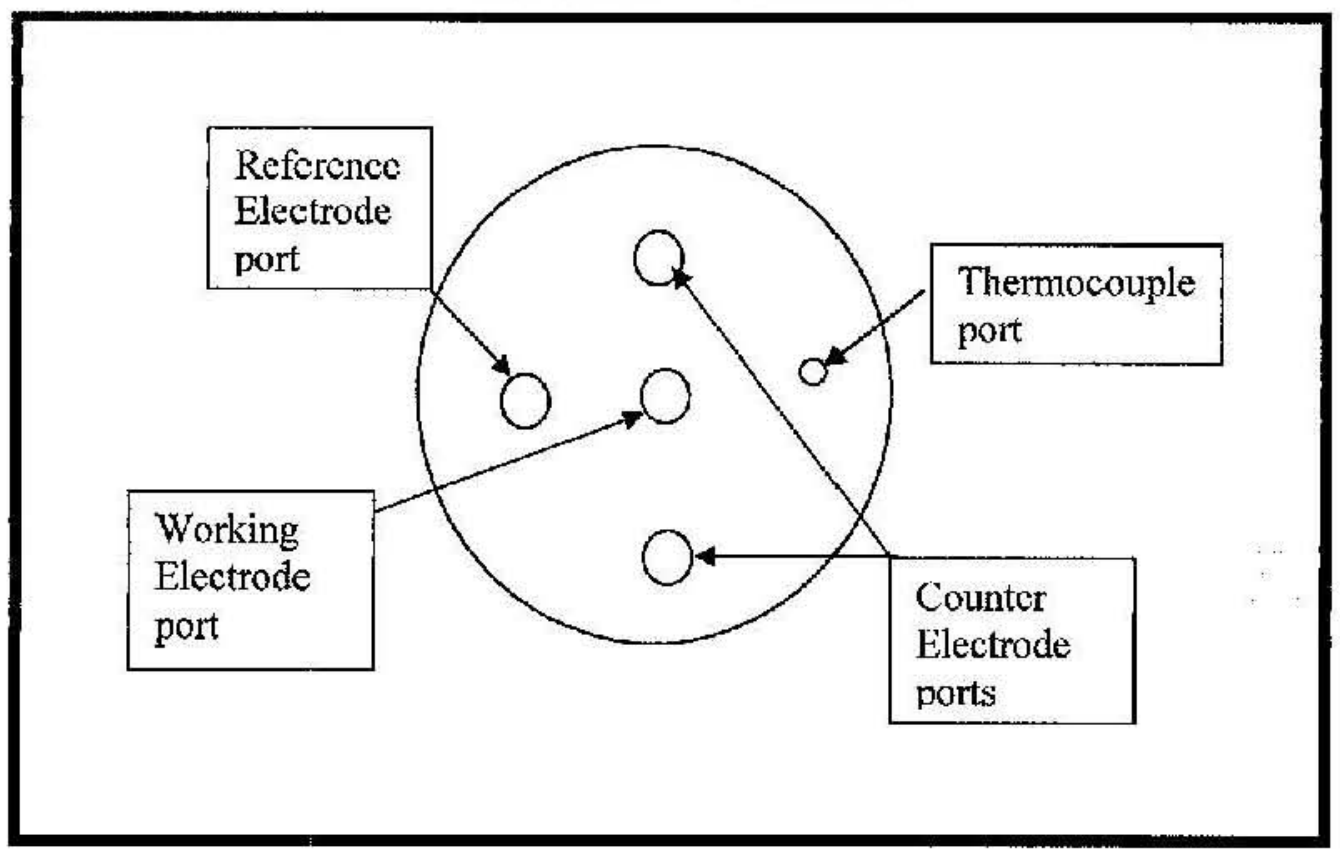

\subsection{5-MILLILITER ELECTROCHEMICAL CELL}

The response of the $125-\mathrm{mL} \mathrm{I}_{\mathrm{C}} \mathrm{CHEM}^{\mathrm{TM}}$ is shown in Figure 2.

During the testing of the $125-\mathrm{mL}$ cell with the configuration of that shown in Figure 1, it was observed that the amperage polarity would shift during the scan over the potential range. It was thought that there was a surface area to electrochemical cell volume effect or a surface area to counter electrode proximity effect. The effect was perhaps due to mass transfer effects as product accumulated at the counter and working clcetrodes and influencing current polarity.

The lirst experiment was designed to spatially separate the working and counter electrode to maximum extent possible. The working electrode was placed 180 degrees from the counter electrode, both at opposite ends of the lid. As shown in Figure 2, the separation did not result in an acceptable response.

Another experiment was designed to decrease the available surface area on the working electrode by occluding much of the surface area with nonconducting material. The available surface area was decreased from $5.64 \mathrm{~cm}^{2}$ to $1.25 \mathrm{~cm}^{2}$, with the counter electrode and working electrode placed as indicaled in Figure 1. The response was somewhat more acceptable but not to the extent that it was deemed appropriate. It was beyond the scope of the project to solve the $125-\mathrm{mL}$ response as observed, and the $125-\mathrm{mL}$ cell was abandoned. 
Figure 2. Response of the 125-Milliliter Electrochemical Cell using the ASTM G5 94 Method.

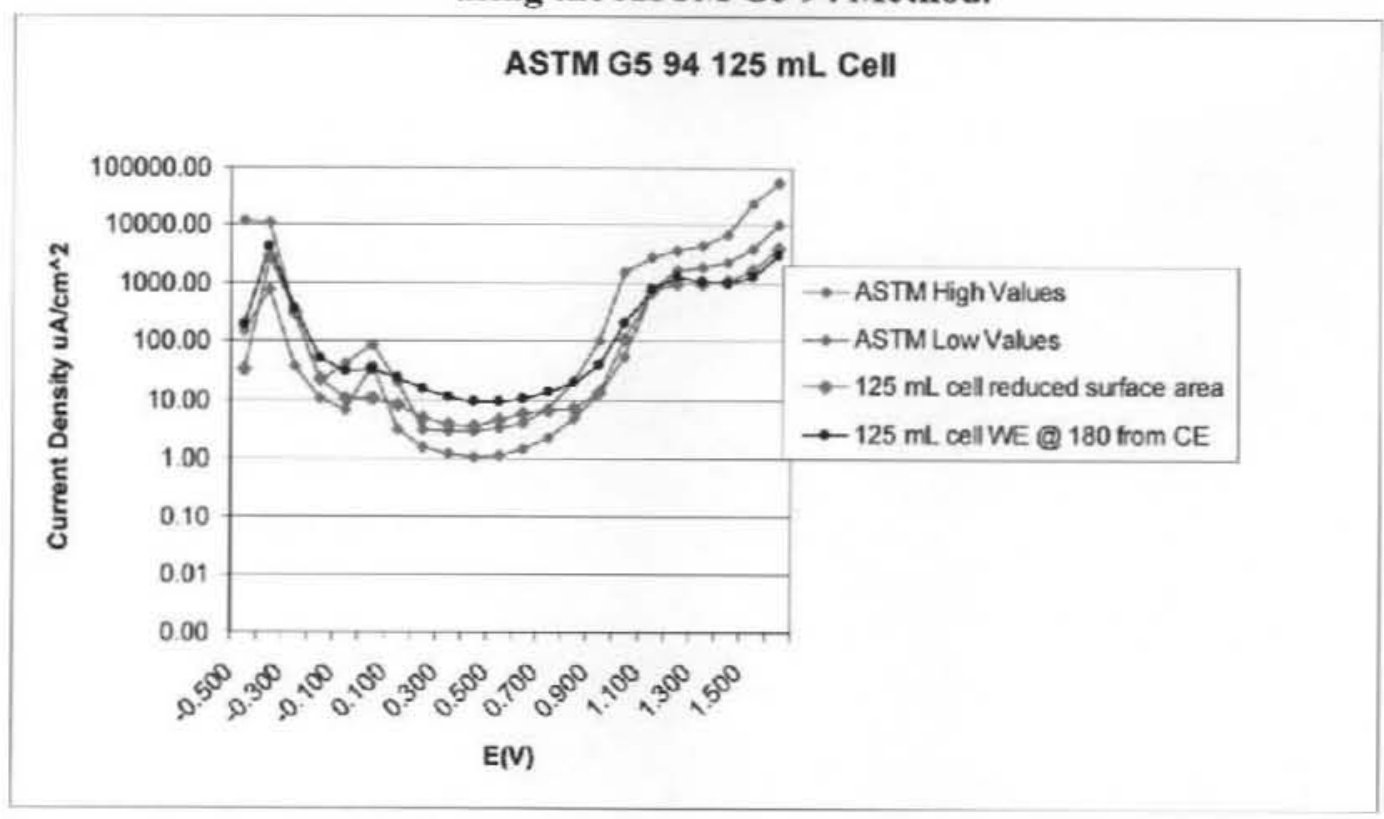

\subsection{0- MILLILITER ELECTROCHEMICAL CELL}

The response of the 250-mL I-CHEM ${ }^{\mathrm{TM}}$ is shown in Figure 3.

Figure 3. Response of the 250-Milliliter Electrochemical Cell using ASTM G5 94 Method.

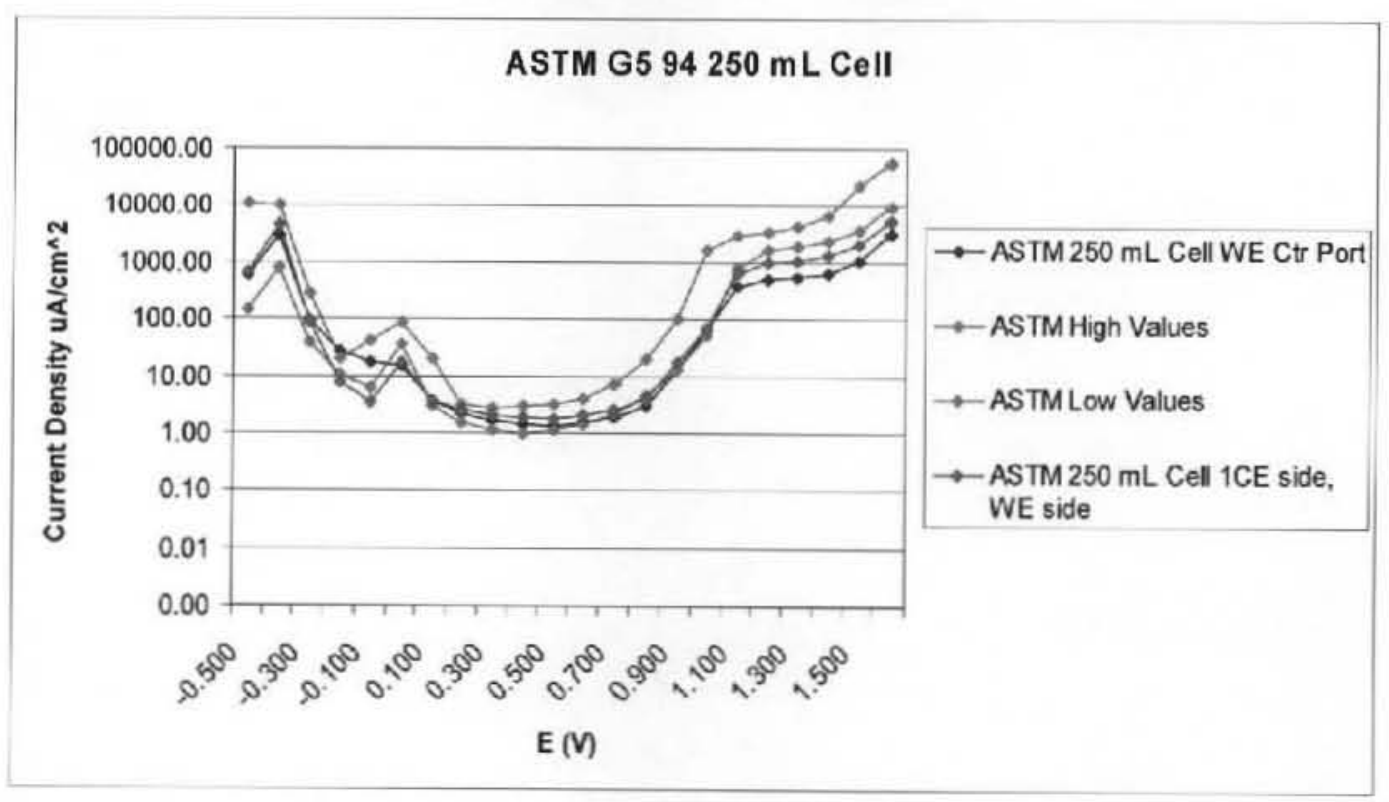


The counter electrodes were placed as noted in Figure 4. This configuration was somewhat acceptable; however, it was decided to configure the cell with the working electrode and the countcr electrode diamctrically opposed and the reference elcetrode (saturated calomel) in the center port. The response is shown in Figure 3 and noted as $1 \mathrm{CE}$ side, WE side. This configuration appeared to have the most favorable response to the ASTM G5-94 method and was adopted for the SY-102 supernatant electrochemical corrosion scans. Figure 4 indicates the positions of the counter electrode, working electrode, and the reference electrode.

\section{Figure 4. Plan View of Electrochemical Ccll Lid with} Two Counter Electrodes.

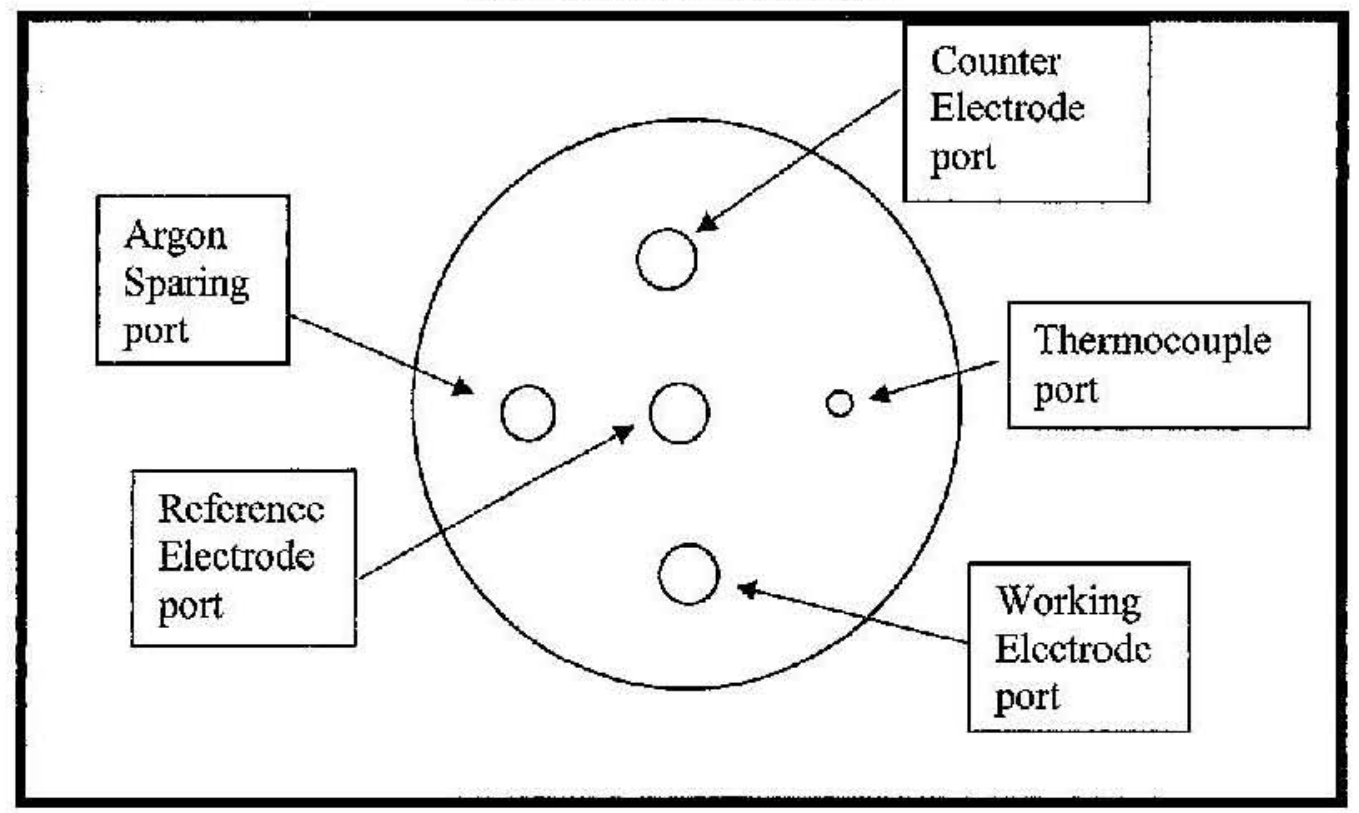

\subsection{DESCRIPTION OF ELECTROCHEMICAL SCANS}

Cylindrical corrosion coupons of $\Lambda 516$ Grade 65 carbon steel were purchased from Metal Samples (Munford, Alabama). The coupons were tapped to receive a threaded electrode. The exposed surface area of the coupon is $5.64 \mathrm{~cm}^{2}$. A PARSTAT $2263^{3}$ was used for the electrochemical scans.

A fresh coupon was used for each scan. The coupon was immersed in the sample and allowed to equilibrate for 1 hour. Scans were first carried out with the sample as received; for the second scan, argon was used to purge the sample during the equilibration time. The scans were initiated at $-300 \mathrm{mV}$ versus the open circuit potential (OCP) and reversed at a current density of $2.5 \mathrm{~mA} / \mathrm{cm}^{2}$ (ASTM G61-86, Standard Test Method for Conducting Cyclic Potentiodynamic Polarization Measurements for Localized Corrosion Susceptibility of Iron-, Nickel-, or CobaltBased Alloys); this reversal was at $550 \mathrm{mV}$ to $700 \mathrm{mV}$, depending on the SY-102 sample.

\footnotetext{
${ }^{3}$ PARSTAT is a rcgistcred trademark of Princeton Applied Research, Tennessee.
} 
The electrochemical cell employed was a $250{\mathrm{~mL} \mathrm{I}-\mathrm{CHEM}^{4} \text { with a Rexolite }}^{5}$ lid. The lid contained ports to allow the saturated calomel reference electrode (Radiometer ${ }^{6}$ ) access to the solution via a Luggin bridge filled with $1 \mathrm{M}$ potassium nitrate. The electrochemical cell consisted of one graphite rod as the counter electrode, the saturated calomel electrode, and the working electrode of A516 carbon steel, in that order.

\subsection{INSTRUMENT AND LEAD VERIFICATION TESTS}

The electrochemical corrosion laboratory effort was executed under the HNF-SD-CP-QAPP-016, 222-S Laboratory Quality Assurance Plan. The leads and instrument check was employed using a 48-K-ohm resistor and the ASTM G5-94 method. The potentiostat was used to run a chronoamperometry measurement around the resistor. The potential was set at $0.220 \mathrm{~V}$ against the $48 \mathrm{~K} \mathrm{Ohm}$ resistor ( $+1-10 \%$ tolerance). The potentiostat returned a current reading of $4.59 \mathrm{E}-06 \mathrm{~A}$. This indicated the leads and instrument were functioning at a point source.

To ascertain the response of the potentiostat, the ASTM G5-94 method was run both before the SY-102 samples were scanned and again after the last SY-102 sample. In both cases, the response of the PARSTAT $2263^{18}$ compared to the high and low reported values of the ASTM participating laboratories. Figure 5 shows the response of the potentiostat.

Figure 5. Electrochemical Response to ASTM G5-94 Method.

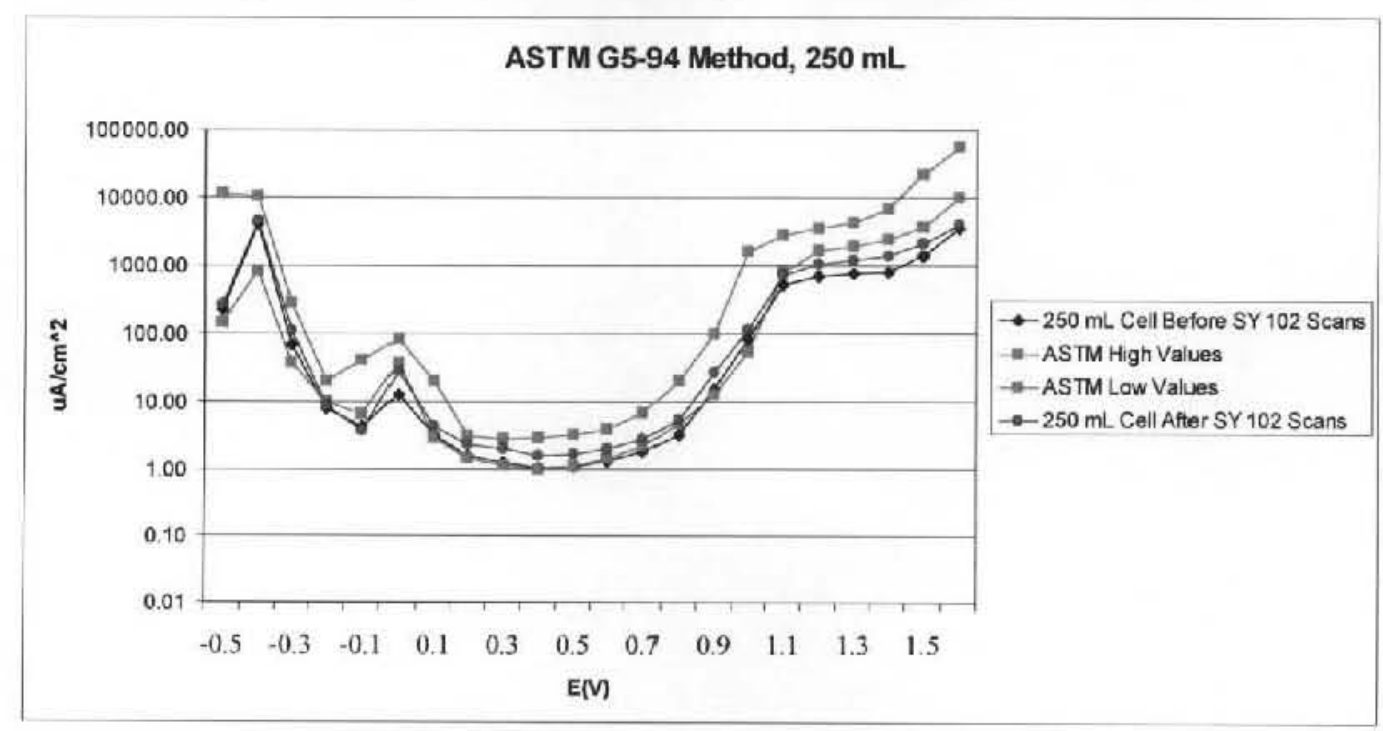

\footnotetext{
${ }_{5}^{4}$ Nalge Nunc International Corporation Rochester, New York.

${ }^{5}$ Rexolite is a registered trademark of C-LEC Plastics, Inc., Corporation, Philadelphia, Pennsylvania.

${ }^{6}$ Radiometer is a registered trademark of Radiometer Analytical S.A., Lyon, France.
} 


\subsection{RESULTS AND DISCUSSION OF ELECTROCHEMICAL SCANS}

The samples were subjected to cyclic scans that were carried out from $-300 \mathrm{mV}$ versus OCP to a current density of $2.5 \mathrm{~mA} / \mathrm{cm}^{2}$. Table 4 presents the data associated with and without argon purge. The argon purge and scan were performed after a cyclic potentiodynarnic scan was performed on the as-received sample. The scans with and without argon are presented in Appendix A.

Table 4. Results of Electrochemical Cyclic Polarization Scans for Tank 241-SY-102 Supernate.

\begin{tabular}{|c|c|c|c|c|c|c|}
\hline \multirow{2}{*}{$\begin{array}{c}\text { Sample } \\
\text { (distance } \\
\text { from } \\
\text { bottom, } \\
\text { inches) }\end{array}$} & \multicolumn{3}{|c|}{ Without Argon Purge } & \multicolumn{3}{|c|}{ With Argon Parge } \\
\hline & $\begin{array}{l}\text { OCP } \\
(\mathrm{mV})\end{array}$ & $\begin{array}{c}\text { Corrosion } \\
\text { Rate } \\
\text { (mpy) }^{b}\end{array}$ & ${ }^{2} x^{2}$ & OCP & $\begin{array}{c}\text { Corrosion } \\
\text { Rate } \\
\text { (mpy) }\end{array}$ & ${ }^{a} \chi^{2}$ \\
\hline $\begin{array}{l}\text { 2SY-04-05 } \\
(271.2)\end{array}$ & -350 & 0.039 & 49.3 & -540 & 0.014 & 83.7 \\
\hline $\begin{array}{l}2 S Y-04-06 \\
(256.2)\end{array}$ & -430 & 0.039 & 20.3 & -360 & 0.018 & 47.9 \\
\hline $\begin{array}{l}\text { 2SY-04-06 } \\
\text { DUP } \\
(256.2)\end{array}$ & -428 & 0.028 & 44.3 & -580 & 0.012 & 44.1 \\
\hline $\begin{array}{l}\text { 2SY-04-07 } \\
(117.2)\end{array}$ & -430 & 0.038 & 23.5 & -560 & 0.013 & 59.1 \\
\hline $\begin{array}{l}2 S Y-04-08 \\
(55.2)\end{array}$ & -390 & 0.039 & 16.8 & -583 & 0.019 & 31.4 \\
\hline
\end{tabular}

" $\chi^{2}$ - goodness of fit statistic, to the Stem-Geary equation, Typical values for reasonably good fits will range between 2 and 100 .

$\mathrm{OCP}=$ open circuit potential.

mpy $=$ mils per year.

It should be noted that during the argon purge, there was vigorous foaming at low purge volumes. To ensure the sample did not "boil over," argon was introduced very slowly and carefully watched until a "steady state" was obtained with the foaming response.

As may be seen from Table 4 , corrosion rates ranged from 0.028 mpy to 0.039 mpy for nonargon sparged and $0.012 \mathrm{mpy}$ to $0.019 \mathrm{mpy}$ for argon sparged. It is thought that the displacement of oxygen by argon may be responsible for the smaller corrosion rate. To state this with empirical evidence is beyond the scope of the testing.

A test for stress corrosion cracking was carried out on sample 2SY-04-07 using the proccdure described in Predictive Approaches to Stress Corrosion Cracking Failure by Parkin (1980). The Parkin procedure is carried out as follows; the fast and slow scan overlays are shown as Figure A-11 in Appendix A.:

a. Prepare a coupon and allow it to equilibrate for 1 hour under open circuit condition. 
b. Sct the potentiodynamic scan to condition the coupon at $100 \mathrm{mV}$ (cathodic) versus the OCP for 5 minutes.

c. After the conditioning step, follow with a potentiodynamic sweep from $-100 \mathrm{mV}$ versus OCP to $1 \mathrm{~V}$ versus saturated calomel clcctrode with a sweep rate of $0.333 \mathrm{mV} / \mathrm{sec}$.

d. Repeat the above procedure with a second coupon and scan at a rate of $16.7 \mathrm{mV} / \mathrm{s}$.

For the analysis of the Parkin ratio:

a. Compare the two traces where the current is above $1 \mathrm{~mA} / \mathrm{cm}^{2}$.

b. For the potential region where the current is greater than $1 \mathrm{~mA} / \mathrm{cm}^{2}$, calculate the difference in the currents between the fast and slow scans as a function of potential for a number of potentials in the region where the currents meet these critcria.

c. Ratio the fast and the slow data; where the ratio exceeds 1000 , there will be stress corrosion cracking.

For the 2SY-04-07 sample the ratios were well under 1000 (the ratios were measured between 1 and 10); therefore no stress corrosion cracking was exhibited.

\section{REFERENCES}

03-TED-113, 2004, "Contract No. DE-AC27-99RL14047 - Approval of Justification for Continued Operation (JCO) for Double-Shell Tank (DST) 24I-SY-102," (external letter from R. J. Schepens, ORP, to E. S. Aromi, CH2M HILL, December 2), U.S. Department of Energy, Office of River Protection, Richland, Washington.

03-TED-117, 2003, "Contract No. DE-AC27-99RL14047 - Approval of Justification for Contimued Operation (JCO) for Double-Shell Tank (DST) 241-SY-102" (external letter from R. J. Schepens, ORP, to E. S. Aromi, CH2M HIL.., November 19), U.S. Department of Energy, Office of River Protection, Richland, Washington.

7S120-RWS-05-002, 2005, "Analytical Results for 241-SY-102 Grab Sampling and Analysis Plan: Transfer and Retrieval Support" (internal letter from R. W. Sosa to N. W. Kirch, January 24), CH2M HILL Hanford Group, Inc., Richland, Washington.

ASTM G5-94, 1994 (Reapproved 1999), Standard Reference Test Method for Making Potentiostatic and Potentiodynamic Anodic Polarization Measurements, ASTM International, West Conshohocken, Pennsylvania.

ASTM G61-86, 1986 (Reapproved 2003), Standard Test Method for Conducting Cyclic Potentiodynamic Polarization Measurements for Localized Corrosion Susceptibility of Iron-, Nickel-, or Cobalt-Based Alloys, ASTM International, West Conshohocken, Pennsylvania. 
CH2M-0304014 R2, 2004, "Contract Number DE-AC27-99RL14047 - Extension of Justification for Continued Operation for Double-Shell Tank 241-SY-102" (externaI lctter from E. S. Aromi, CH2M HILL, to R. J. Schepens, ORP, November 24), CH2M HILL Hanford Group, Inc., Richland, Washington.

HNF-SD-CP-QAPP-016, 2004, 222-S Laboratory Quality Assurance Plan, Rev. 8, CH2M HILL Hanford Group, Inc., Richland, Washington.

HNF-SD-WM-TSR-006, 2005, Tank Farms Technical Safety Requirements, "Cortosion Mitigation Program," Section 5.16, current revision, CH2M HILL Hanford Group, Inc., Richland, Washington.

Parkin, R. N., Predictive Approaches to Siress Corrosion Cracking Failure; Corrosion Science, 20: 147-266, 1980.

RPP-18195, 2004, Tank 241-SY-102 Grab Sampling and Analysis Plan: Transfer and Retrieval Support, Rev. 1, CH2M HILL Hanford Group, Inc., Richland, Washington.

RPP-18694, 2003, Tank 24l-S-112 Retrieval Process Flowsheet Calculation, Rev. 0, CH2M HILL Hanford Group, Inc., Richland, Washington.

RPP-PLAN-23585, 2005, Test Plan and Procedure for Electrochemical Corrosion Studies of Tank 241-SY-102 Supernatant, Rev. 0, CH2M HILL Hanford Group, Inc., Richland, Washington. 
RPP-RPI-27766, Rev. 0

APPENDIX A

\section{CYCLIC POLARIZATIION SCANS}

TANK 241-SY-102 SUPERNATANT 
Figure A-1. Sample 2SY-04-05, without Argon Sparge, Potential Measured against a

Saturated Calomel Electrode, Scan Temperature $50^{\circ} \mathrm{C}$.

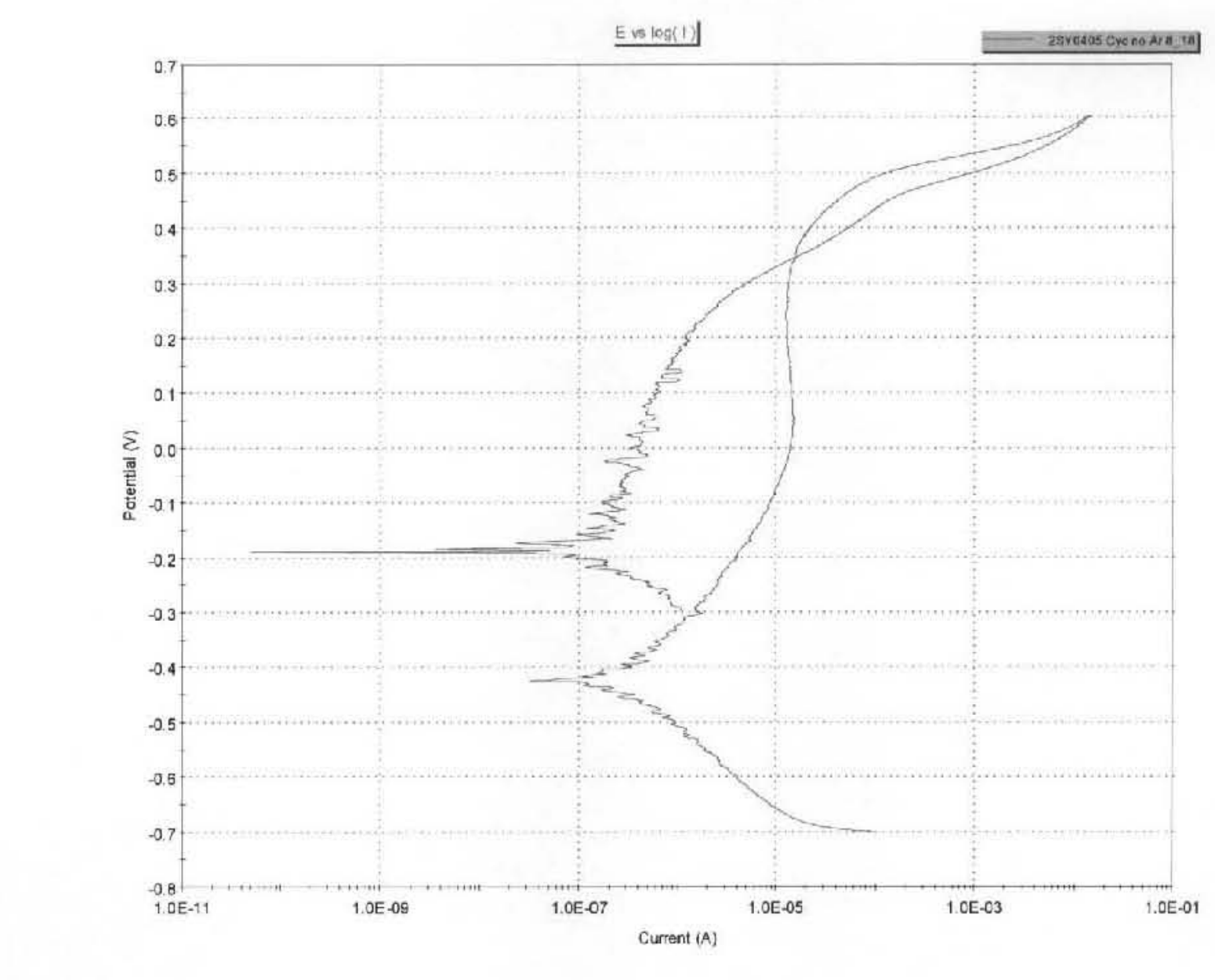

\section{Saturated Calomel Electrode, Scan 'Temperature $50^{\circ} \mathrm{C}$.}

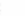




\section{RPP-RPT-27766, Rev. 0}

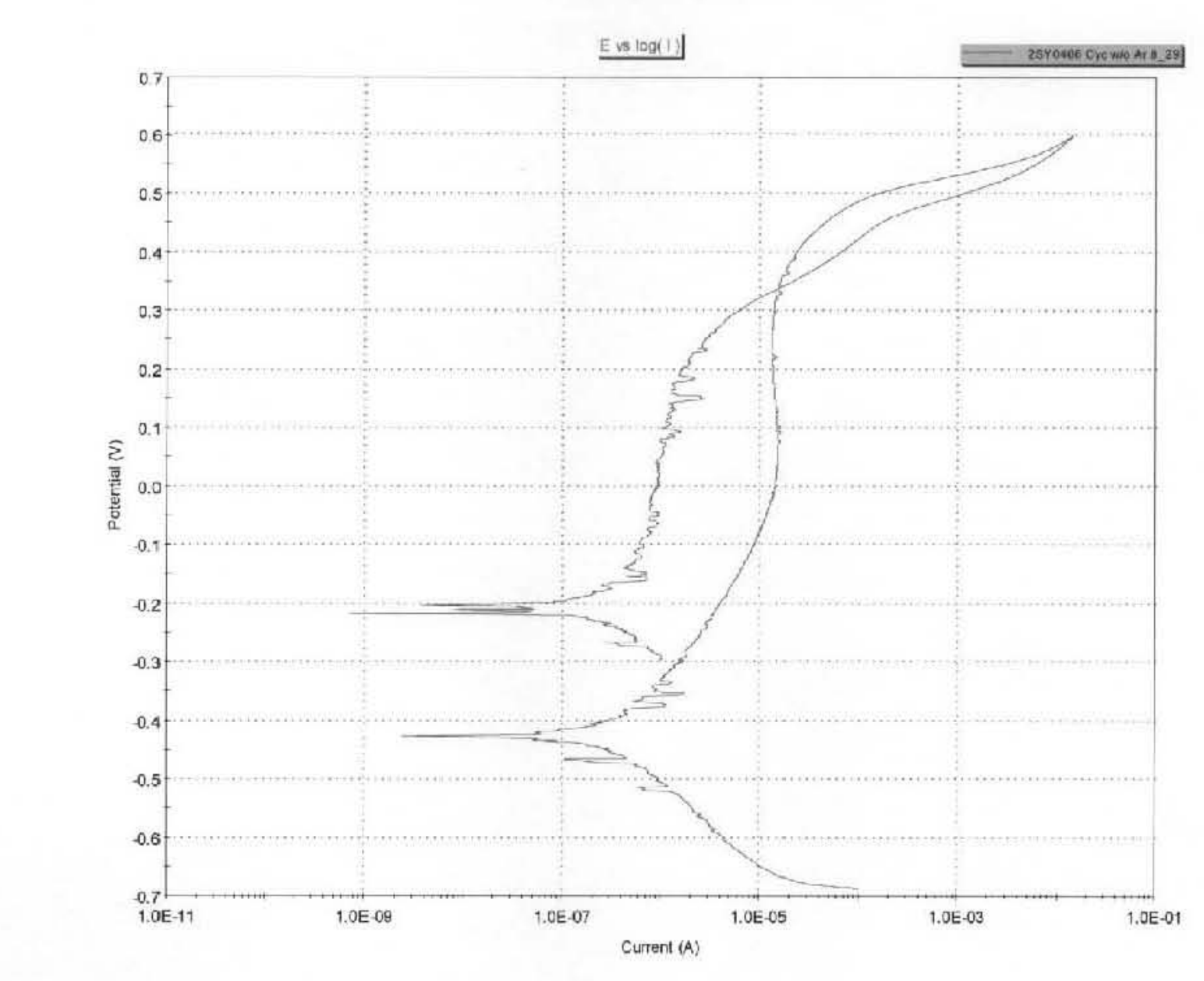

\section{Figure A-2. Sample 2SY-04-06, without Argon Sparge, Potential Measured against a Saturated Calomel Electrode, Scan Temperature $50^{\circ} \mathrm{C}$. \\ Figure A-2. Sample 2SY-04-06, without Argon Sparge, Potential Measured against a}

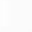




\section{RPP-RPT-27766, Rev. 0

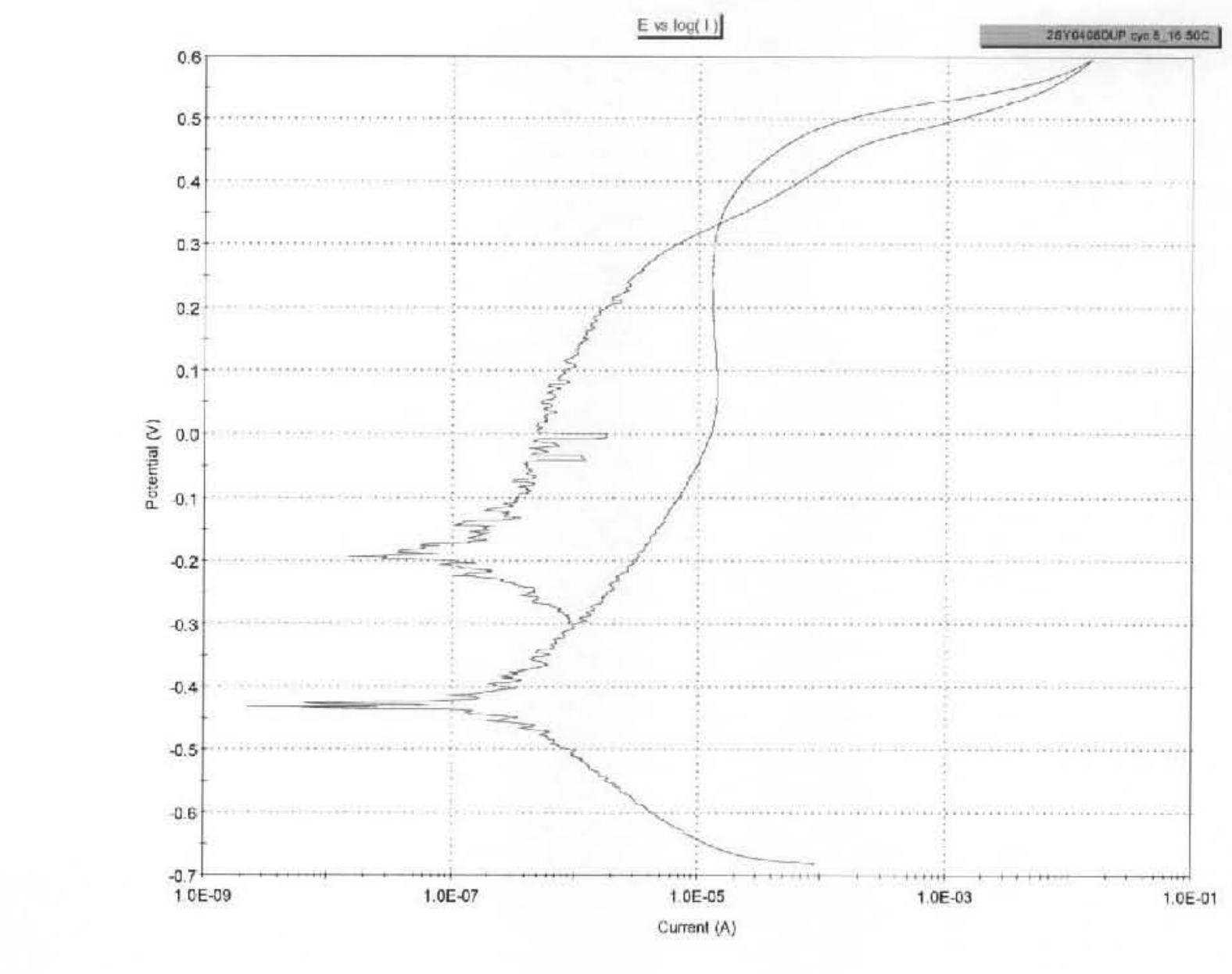

\section{Figure A-3. Sample 2SY-04-06 DUP, without Argon Sparge, Potential Measured against a Saturated Calomel Electrode, Scan Temperature $50^{\circ} \mathrm{C}$.}

a 


\section{RPP-RPT-27766, Rev. 0}

Figure A-4. Sample 2SY-04-07, without Argon Sparge, Potential Measured against a Saturated Calomel Electrode, Scan Temperature $50^{\circ} \mathrm{C}$.

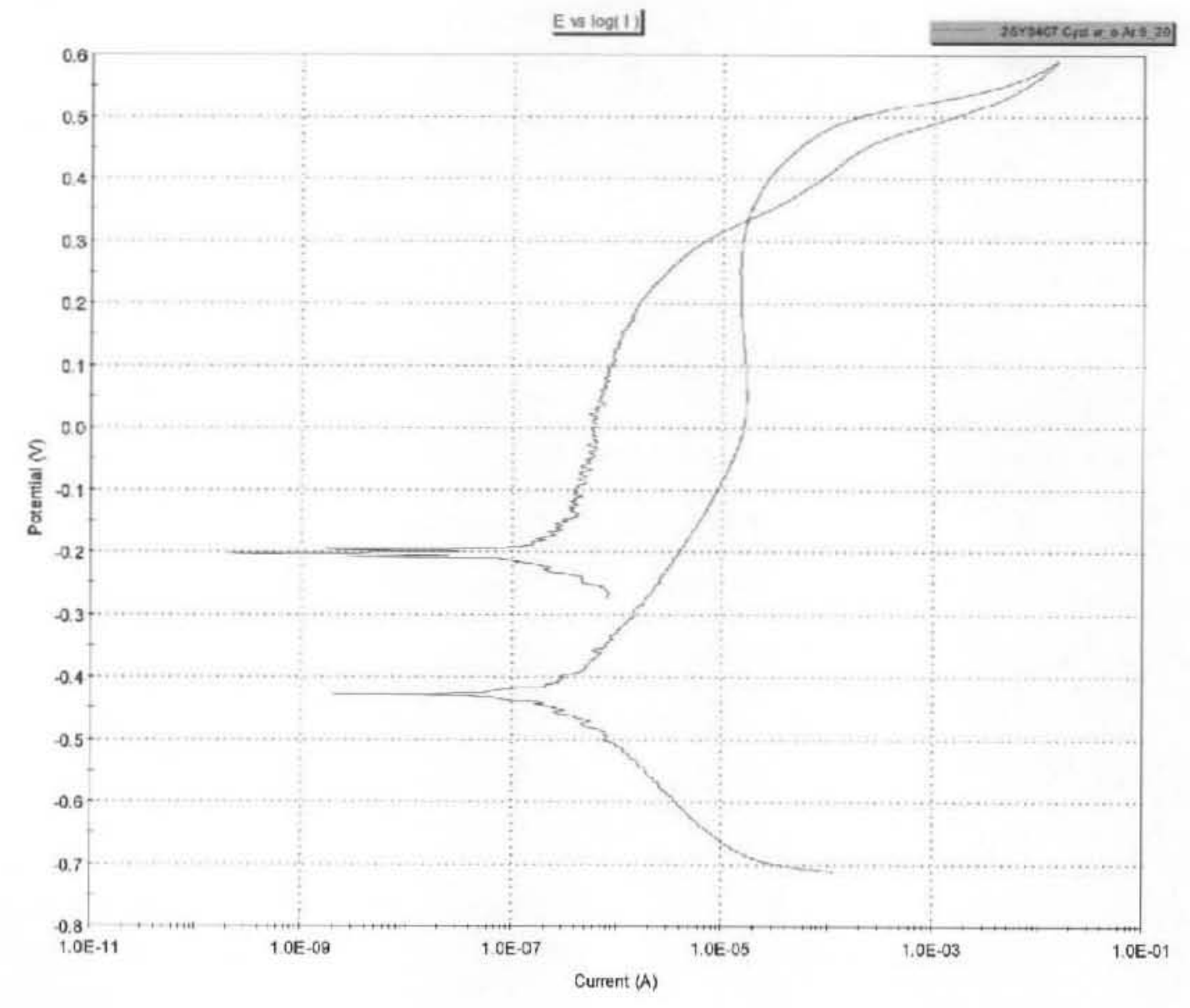

\section{against a Saturated Calomel Electrode, Scan 'Tempernture 50 ${ }^{\circ}$.}


Figure A-5. Sample 2SY-04-08, without Argon Sparge, Potential Measured against a Saturated Calomel Electrode, Scan Temperature $50^{\circ} \mathrm{C}$.

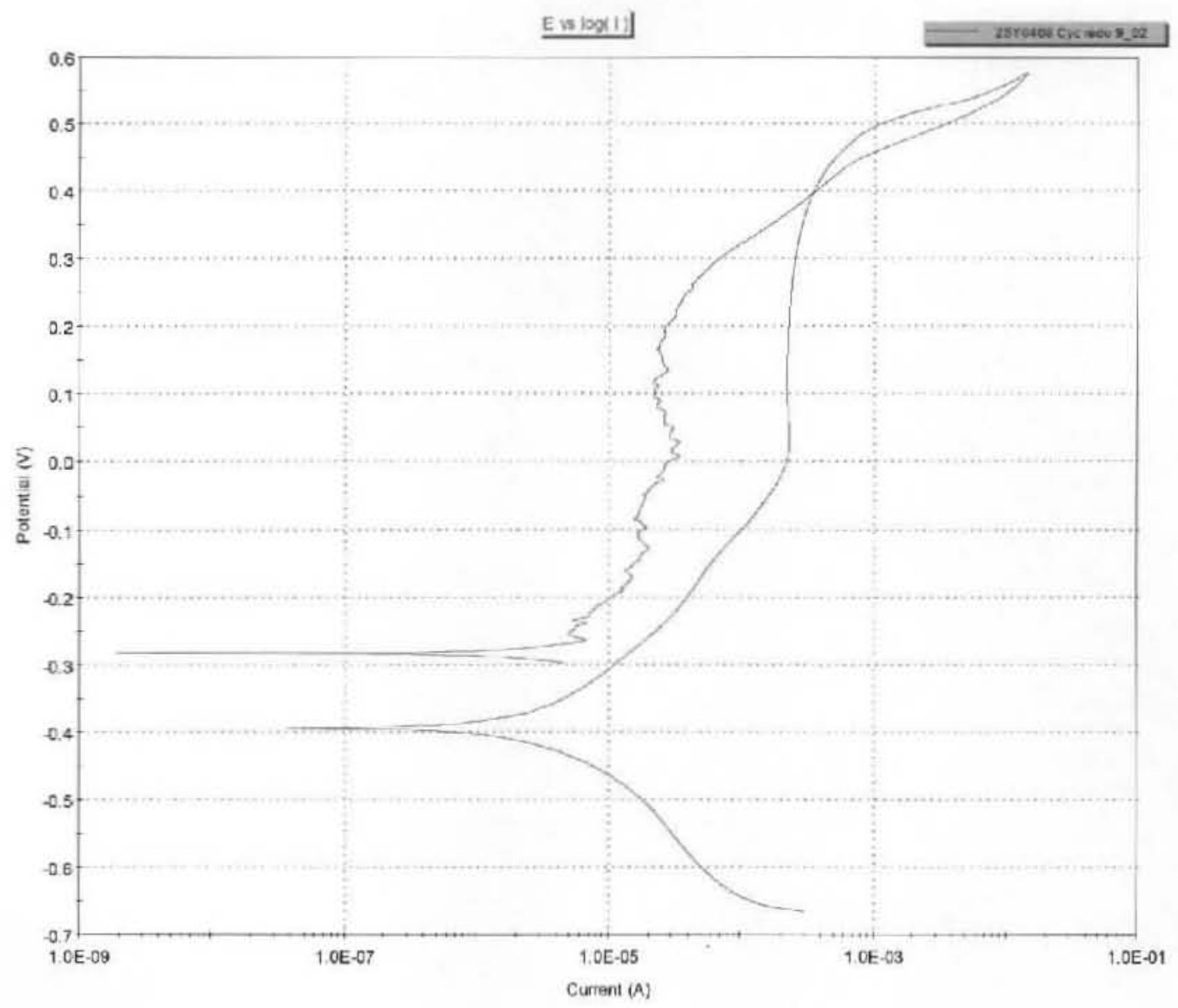


Figure A-6. Sample 2SY-04-05, with Argon Sparge, Potential Measured

against a Saturated Calomel Electrode, Scan Temperature $50{ }^{\circ} \mathrm{C}$.

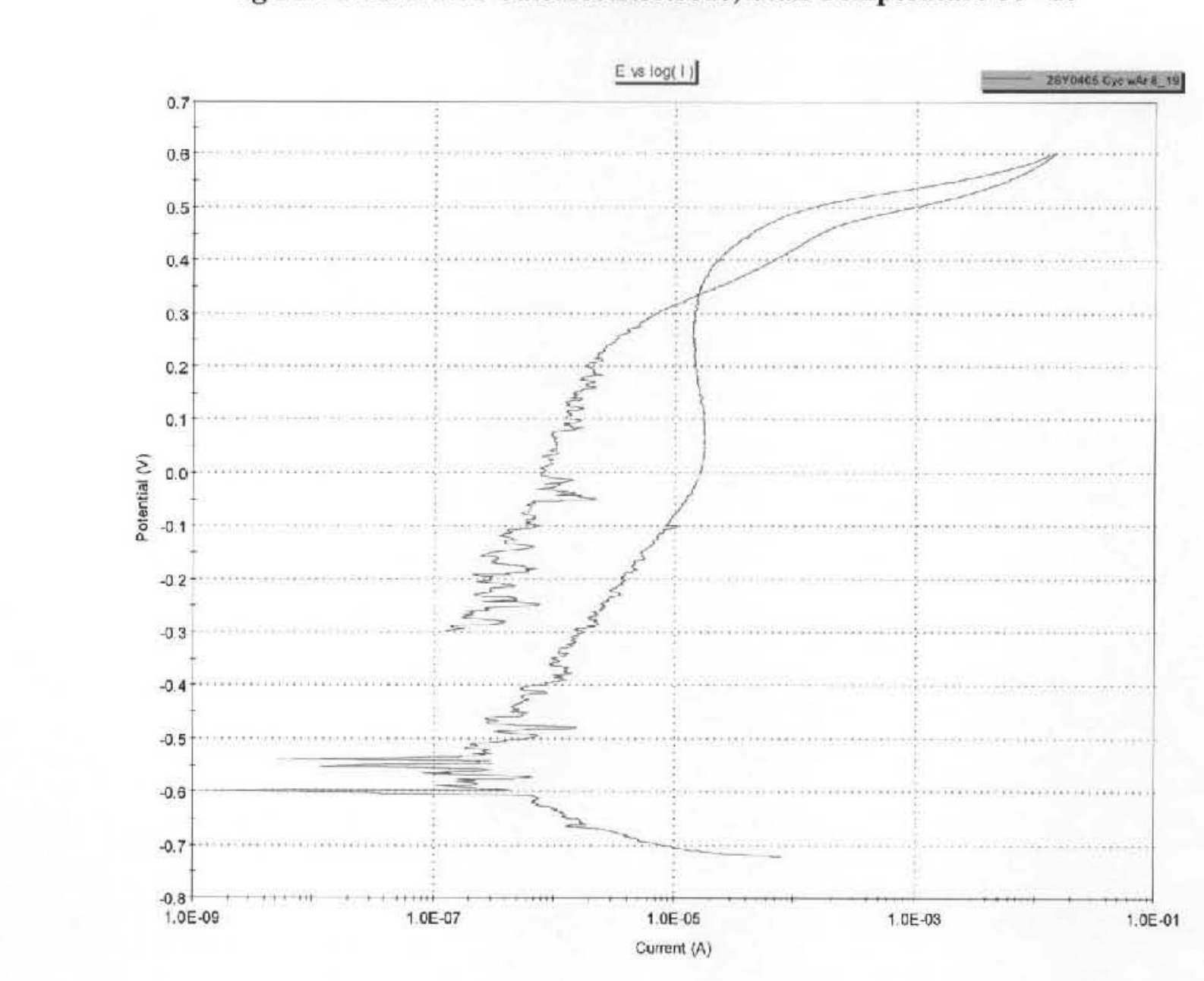

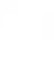




\title{
RPP-RPT-27766, Rev. 0
} against a Saturated Calomel Electrode, Scan Temperature $50{ }^{\circ} \mathrm{C}$.

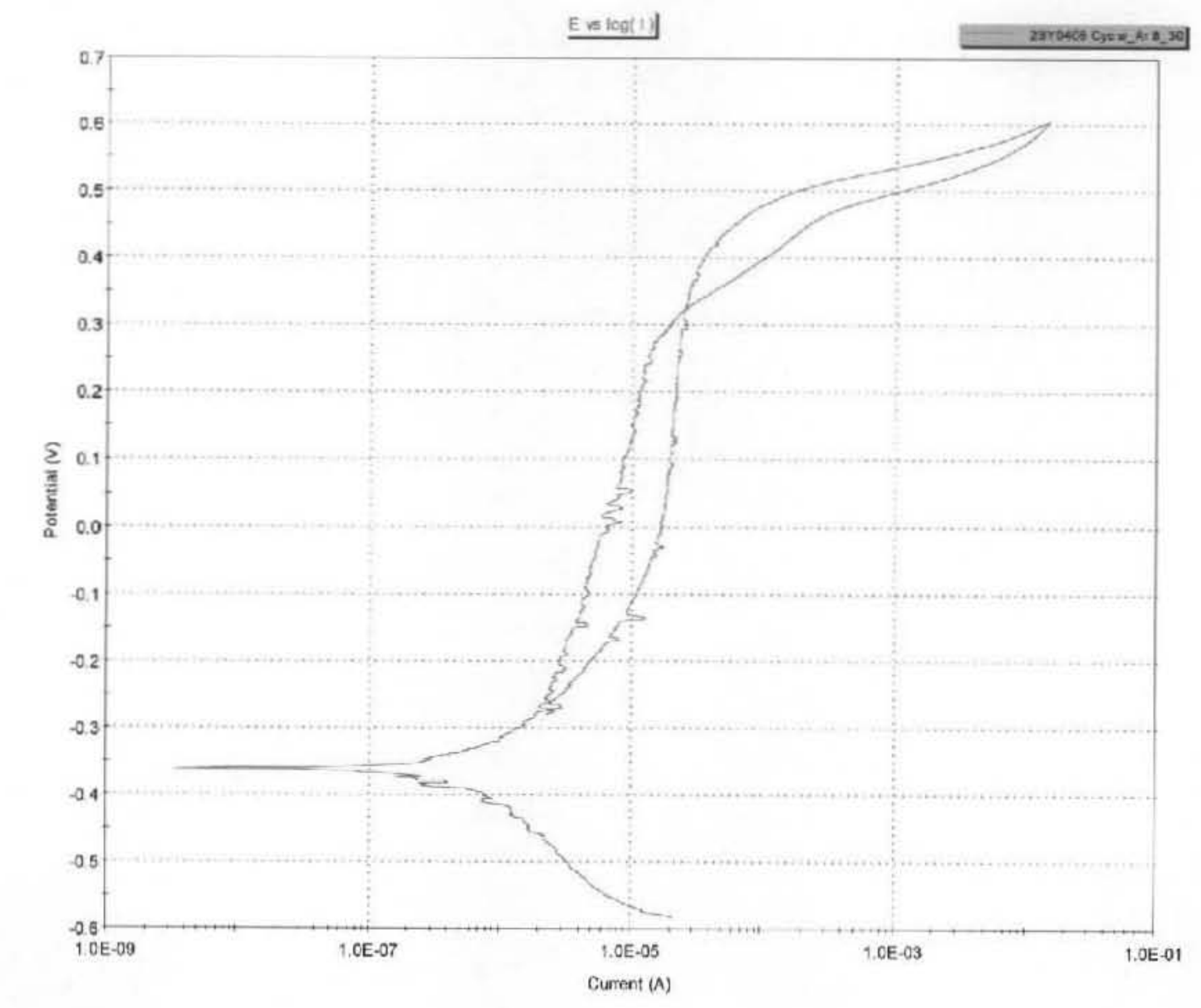

\section{Figure A-7. Sample 2SY-04-06, with Argon Sparge, Potential Measured}

\begin{abstract}
against a Saturated Calomel Electrode, Scan Temperature $500^{\circ} \mathrm{C}$
\end{abstract}




\title{
RPP-RPT-27766, Rev. 0
}

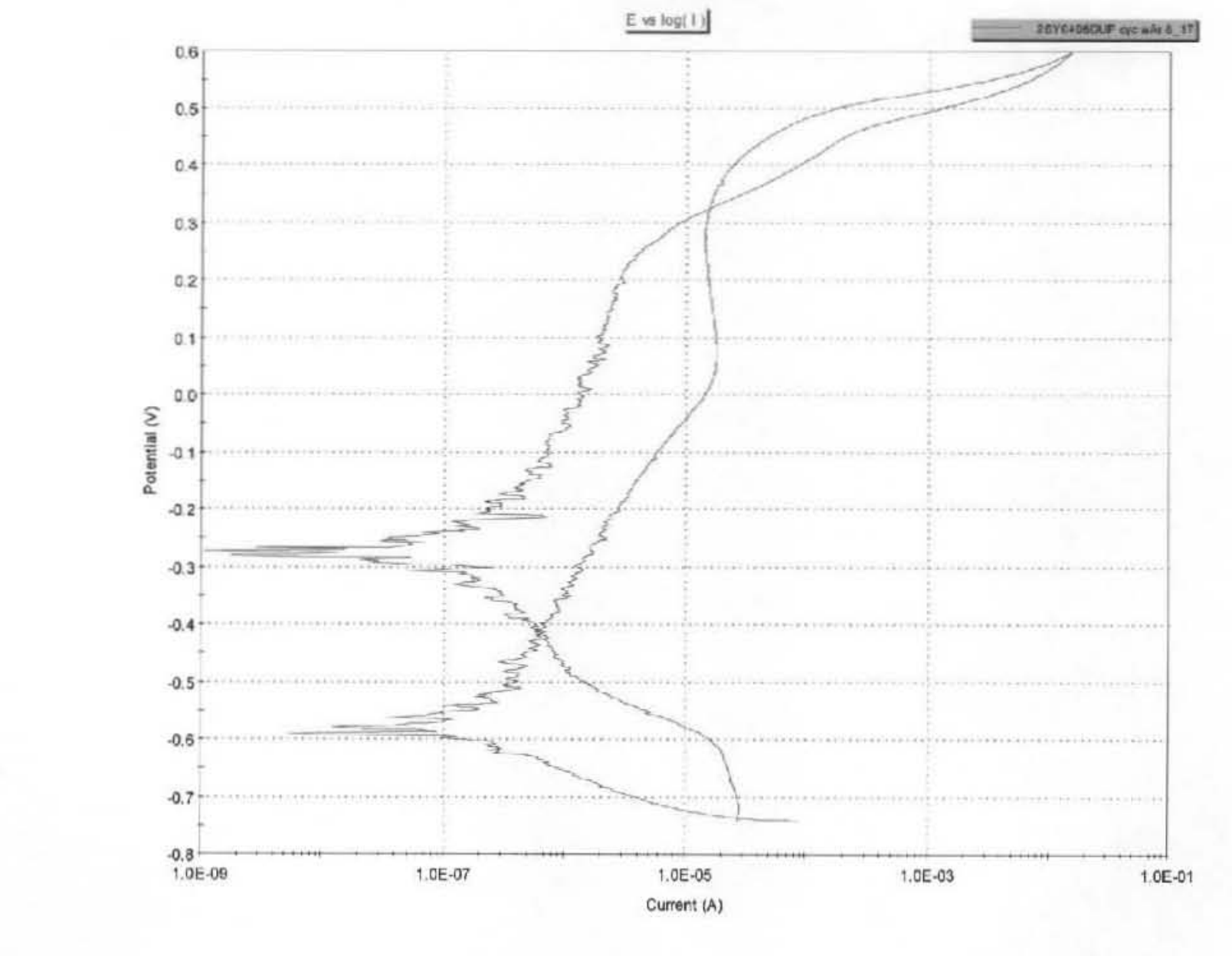

\section{Figure A-8. Sample 2SY-04-06 DUP, with Argon Sparge, Potential Measured}

\begin{abstract}
against a Saturated Calomel Electrode, Scan Temperature $50^{\circ} \mathrm{C}$.
\end{abstract}

\section{against a Saturated Calomel Electrode, Scan Temperature $50^{\circ} \mathrm{C}$.}

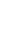

(1) 


\section{RPP-RPT-27766, Rev. 0}

Figure A-10. Sample 2SY-04-08, with Argon Sparge, Potential Measured against a Saturated Calomel Electrode, Scan Temperature $50^{\circ} \mathrm{C}$.

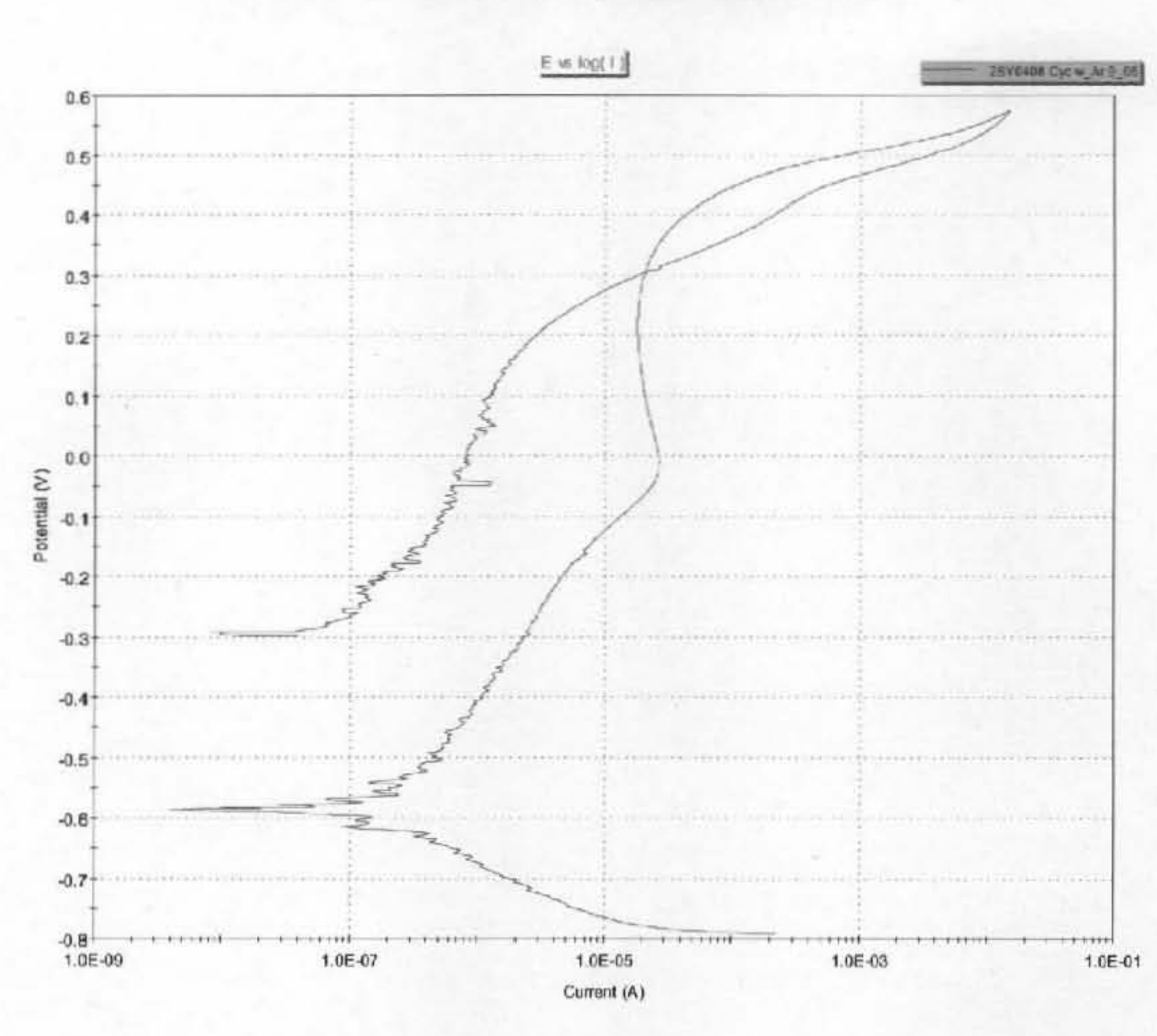
(1)

.

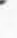

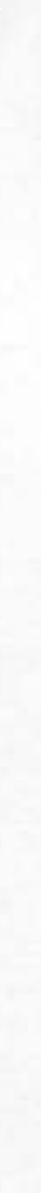

(1)

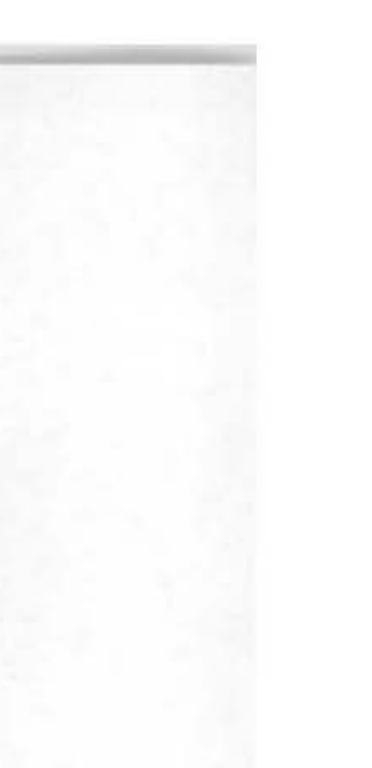


Figure A-11. Fast and Slow Scan Overlays for the Parkin Method for Stress Corrosion

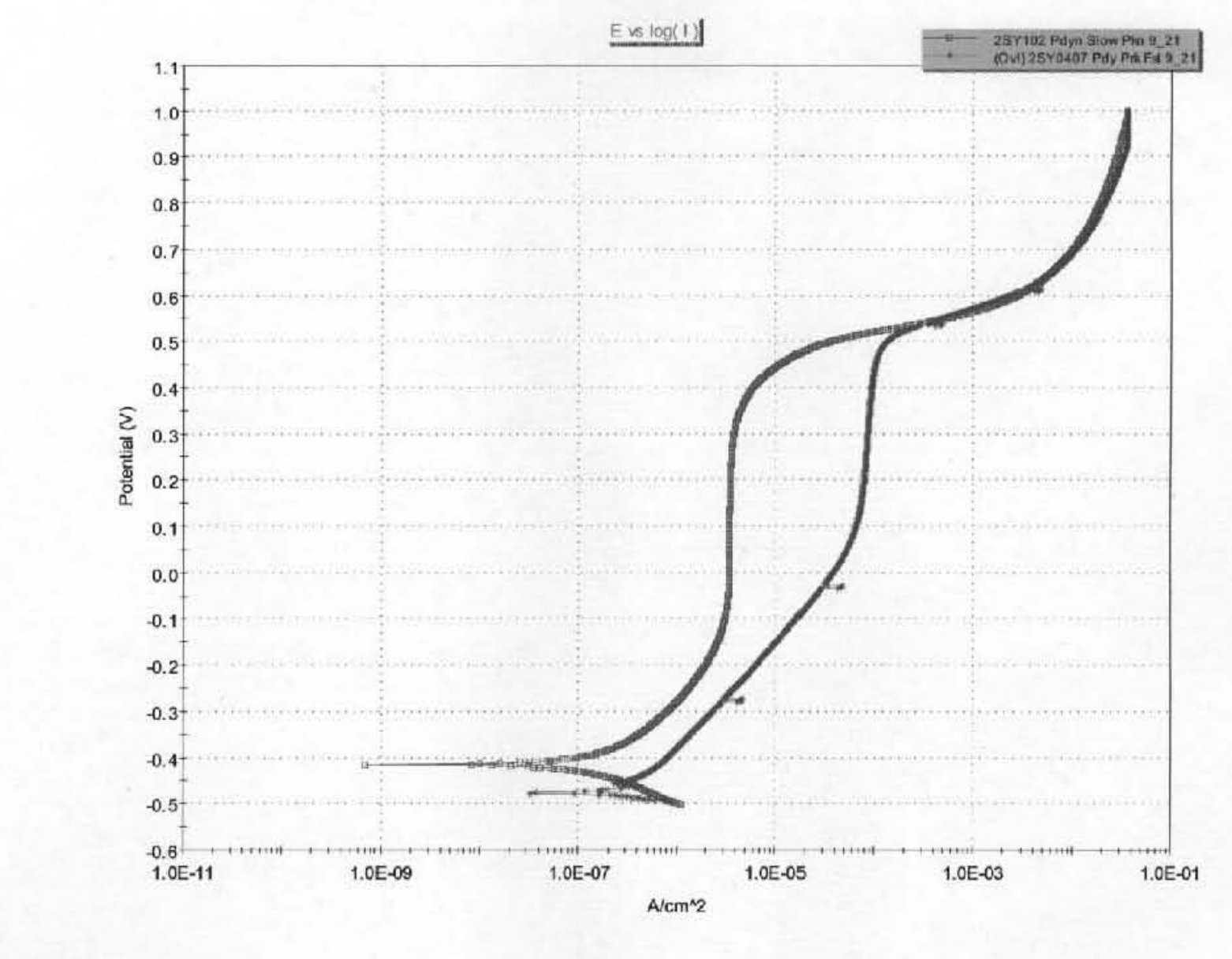

\section{Cracking against a Saturated Calomel Electrode, Scan Temperature $50^{\circ} \mathrm{C}$.}

RPP-RPT-27766, Rev. 0

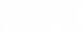

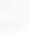

